\title{
Inhibition of urokinase plasminogen activator "uPA" activity alters ethanol consumption and conditioned place preference in mice
}

This article was published in the following Dove Press journal:

Drug Design, Development and Therapy

16 September 2014

Number of times this article has been viewed

\author{
Elyazia Al Maamari* \\ Mouza Al Ameri \\ Shamma Al Mansouri \\ Amine Bahi*
}

Department of Anatomy, College of Medicine and Health Sciences, United Arab Emirates University,

Al Ain, United Arab Emirates

*These authors contributed equally to this work
Correspondence: Amine Bahi Department of Anatomy, College of Medicine and Health Sciences, United Arab Emirates University, PO Box 17666, Al Ain, United Arab Emirates

Tel +971 37137516

Fax +97I 37672033

Email amine.bahi@uaeu.ac.ae

\begin{abstract}
Urokinase plasminogen activator, uPA, is a serine protease implicated in addiction to drugs of abuse. Using its specific inhibitor, B428, we and others have characterized the role of uPA in the rewarding properties of psychostimulants, including cocaine and amphetamine, but none have examined the role of uPA in ethanol use disorders. Therefore, in the current study, we extended our observations to the role of uPA in ethanol consumption and ethanolinduced conditioned place preference. The general aim of the present series of experiments was to investigate the effects of the administration of the B428 on voluntary alcohol intake and ethanol conditioned reward. A two-bottle choice, unlimited-access paradigm was used to compare ethanol intake between vehicle- and 3, 10, and $30 \mathrm{mg} / \mathrm{kg}$ B428-administered mice. For this purpose, the mice were presented with an ethanol solution $(2.5 \%-20 \%)$ and water, at each concentration for 4 days, and their consumption was measured daily. Consumption of saccharin and quinine solutions was also measured. Systemic administration of B428 dose-dependently decreased ethanol intake and preference. Additionally, B428 mice did not differ from vehicle mice in their intake of graded solutions of tastants, suggesting that the uPA inhibition did not alter taste function. Also, ethanol metabolism was not affected following B428 injection. More importantly, $1.5 \mathrm{~g} / \mathrm{kg}$ ethanol-induced conditioned place preference acquisition was blocked following B428 administration. Taken together, our results are the first to implicate uPA inhibition in the regulation of ethanol consumption and preference, and suggest that uPA may be considered as a possible therapeutic drug target for alcoholism and abstinence.
\end{abstract}

Keywords: B428, CPP, two-bottle choice

\section{Introduction}

Addiction to psychoactive substances is a worldwide burden, one of which is alcohol addiction. In an analytical epidemiology study conducted by Rehm et al it was reported that alcohol consumption is estimated at $3.2 \%$ of worldwide mortality causes. Excessive alcohol consumption consequences occur at a younger population age, and the burden of the disease, as measured by disability adjusted life years (DALY), is $4.0 \%$ worldwide. ${ }^{1}$ The DALY is a measurement of premature mortality and the years of life lost while living with a disabling disease. ${ }^{1}$ It has been reported, in the Summary Health Statistics for US Adults: National Health Interview Survey 2012, ${ }^{2}$ that in the US alone, $52 \%$ of adults aged 18 and over were current regular drinkers.

Although there is an extensive literature using rodent laboratory animal models to understand the neuropharmacological and molecular mechanisms involved in alcohol drinking and abuse, to date, few effective treatments are available for excessive ethanol drinking and alcoholism. It is well established that the extracellular proteases 
are implicated in the pathophysiology of a number of psychiatric diseases. ${ }^{3,4}$ In addition, a body of evidence has been accumulated supporting that the extracellular protease system modulates the rewarding properties of drug of abuse..$^{5,6}$

The urokinase-type plasminogen activator (uPA) is a secreted inducible extracellular serine protease that binds to its receptor (uPAR), which is a glycosylphosphatidylinositol (GPI)-anchored protein. ${ }^{7,8}$ Activated uPA converts inactive plasminogen into active plasmin, which degrades various components of the extracellular matrix. Besides the function of regulating proteolysis, uPAR could also activate many intracellular signaling pathways that promote cell motility, invasion, proliferation, and survival, through cooperation with transmembrane receptors. ${ }^{9,10}$ It should be emphasized that uPA has attracted attention as an emerging therapeutic target in cancer. ${ }^{11,12}$ Using in situ hybridization, Masos and Miskin screened the whole adult mouse brain for cells expressing the uPA and found it predominantly expressed in the subicular complex, the entorhinal cortex, and the parietal cortex. Also, messenger RNA (mRNA) signals were seen in the basolateral nucleus of the amygdala and in the anterodorsal thalamic nucleus and also, in the dentate gyrus of the hippocampus. ${ }^{13}$ Using, a transgenic approach, the same group reported that mice that overexpress uPA in the brain ( $\alpha$ MUPA mice) performed poorly in tasks of spatial, olfactory, and taste-aversion learning, while still displaying normal sensory and motor capabilities, ${ }^{14}$ suggesting that uPA plays an important role in learning processes. It is, however, unclear whether the involvement of uPA in learning tasks is dependent on plasminogen activator activity. ${ }^{14}$ The same $\alpha$ MUPA mice exhibited spontaneously reduced food intake and increased life span. ${ }^{15}$ In detail, compared with their parental wild-type control, $\alpha$ MUPA mice spontaneously consumed less food (approximately 20\%), exhibited reduced body weight (approximately 20\%) and length (approximately $6 \%$ ), and also prolonged life span (approximately 20\%). ${ }^{16}$ Using quantitative real-time polymerase chain reaction (PCR) analysis, Froy et al reported that $\alpha$ MUPA mice exhibited robust expression of the clock genes $m$ Per $1, m$ Per $2, m C l o c k$, and $m C r y l$, but not $m B m a l 1$, in the liver. ${ }^{15}$ Previous studies from our laboratory showed that uPA is strongly induced upon cocaine injection. In fact, we have reported that cocaine administration induced two- to six-fold increase of uPA mRNA in the mesolimbic dopaminergic pathway, including the ventral tegmental area (VTA), the nucleus accumbens (NAc), and the hippocampus. ${ }^{17}$ In addition local overexpression of uPA in these brain areas, using letiviral-mediated gene transfer technology, increased cocaine-induced locomotor stimulation. ${ }^{17}$ Most importantly, inhibition of uPA expression, by small interfering RNA (si)RNA-expressing viral vectors, reduced cocaine-induced locomotors activity. ${ }^{18}$

The concept of targeting plasminogen activators to tackle addiction and psychiatric diseases is less well developed, and there is scant preclinical evidence as to the likely effectiveness of this approach. This remains the case, even though we have provided compelling evidence of uPA involvement in the rewarding properties of cocaine. ${ }^{17-20}$ Despite this preponderance of evidence linking uPA to addiction to drug of abuse, to date, no studies have examined the effects of pharmacological blockade of uPA on voluntary ethanol consumption and preference.

The aim of the present work was to assess the effect of B428 on voluntary alcohol intake and ethanol-induced conditioned place preference (CPP). B428 is a uPA inhibitor, which, when administered at lower doses, has been proven to selectively reduce the activity of uPA in rodents. ${ }^{21-25}$ Given the reports that suggest that alcohol intake and alcoholism could be mediated by their interaction with serine proteases activity, ${ }^{26}$ and considering that some of the behavioral effects of psychostimulants depend on the levels of uPA activity, ${ }^{18,19,21}$ we hypothesized that by reducing the uPA activity, B428 will decrease alcohol consumption, and ethanol-induced CPP will be prevented.

\section{Methods and materials}

\section{Animals}

Male adults C57BL/6 mice weighing 20-30 g, obtained from the central breeding facility of the College of Medicine and Health Sciences of the United Arab Emirates University, were used. They were individually housed in Plexiglas ${ }^{\circledR}$ cages on a 12:12 light/dark cycle (light on at 6:00 am), in a room at approximately $22^{\circ} \mathrm{C}$ with a humidity of about $50 \%$. Tap water and rodent pellets, obtained from the National Feed and Flour Production and Marketing Company LLC (Abu Dhabi, UAE), were available ad libitum at all times, except where specified. Bedding was produced locally and autoclaved before use. The local Ethics Committee of the College of Medicine and Health Sciences approved the research procedures (protocol number A37-12).

\section{Drugs}

Ethanol solutions $(2.5 \%, 5 \%, 10 \%$, and $20 \%$; v/v) were prepared from absolute ethyl alcohol (Panreac Quimica SAU, Barcelona, Spain) and diluted using tap water. For taste sensitivity, saccharin sodium salt dihydrate $(0.01 \%, 0.02 \%$, $0.04 \%$, and $0.08 \% ; \mathrm{w} / \mathrm{v})$ and quinine hemisulfate $(10,20,40$, 
and $80 \mu \mathrm{M} ; \mathrm{w} / \mathrm{v}$ ) were purchased from Sigma-Aldrich Corp (St Louis, MO, USA) and were dissolved in tap water. For the CPP experiments, $1.5 \mathrm{~g} / \mathrm{kg}$ ethanol was diluted in isotonic saline $(0.9 \%$ sodium chloride $)(10 \% ; \mathrm{v} / \mathrm{v})$. The specific uPA inhibitor B428 was provided by Dr Bruce A Littlefield of Eisai, Inc., Andover, MA, USA, and was dissolved in isotonic saline and administered by intraperitoneal injection (IP) at a volume of $10 \mathrm{~mL} / \mathrm{kg}$. For ethanol, saccharin, and quinine intake, vehicle or B428 were injected daily 30 minutes before the lights were switched off. However, for the CPP experiments, vehicle or B428 were administered 15 minutes before saline or ethanol, during conditioning sessions.

\section{Two-bottle choice drinking procedure: 24-hour ethanol access}

The two-bottle choice drinking procedure was performed as described previously. ${ }^{27-37}$ In brief, after a 1-week acclimatization period to the animal colony room, mice were presented with free access to an ethanol solution in one drinking $10 \mathrm{~mL}$ pipette, with a stainless steel spout, and water in the other on a daily schedule. These fluids were available for 23 hours every day ( 1 hour was taken for measuring and injecting the animals). In the first experiment, the ethanol solution concentration was increased every 4 days, ranging from $2.5 \%$ to $20 \%(\mathrm{v} / \mathrm{v})$. Therefore, mice were exposed to ethanol for a total of 16 days (four concentrations of ethanol, each for 4 days). The ethanol solution was initially presented on the mouse's left but the positions of the two drinking pipettes were randomly switched each 24 hours to prevent position preference. Table 1 presents a general design of this experiment.

Table I Summary of the experimental procedure used in the two-bottle choice test

\begin{tabular}{|c|c|}
\hline Fluids & Days \\
\hline Baseline water drinking ${ }^{\mathrm{a}}$ & 7 \\
\hline $2.5 \%$ ethanol versus water ${ }^{b}$ & 4 \\
\hline $5 \%$ ethanol versus water ${ }^{\mathrm{b}}$ & 4 \\
\hline $10 \%$ ethanol versus water ${ }^{\mathrm{b}}$ & 4 \\
\hline $20 \%$ ethanol versus water ${ }^{b}$ & 4 \\
\hline Washout/water ${ }^{\mathrm{a}}$ & 7 \\
\hline $0.01 \%$ saccharin versus water ${ }^{\mathrm{b}}$ & 2 \\
\hline $0.02 \%$ saccharin versus water ${ }^{\mathrm{b}}$ & 2 \\
\hline $0.04 \%$ saccharin versus water ${ }^{b}$ & 2 \\
\hline $0.08 \%$ saccharin versus water ${ }^{b}$ & 2 \\
\hline Washout/water ${ }^{\mathrm{a}}$ & 7 \\
\hline I0 $\mu \mathrm{M}$ quinine versus water ${ }^{\mathrm{b}}$ & 2 \\
\hline $20 \mu \mathrm{M}$ quinine versus water ${ }^{\mathrm{b}}$ & 2 \\
\hline $40 \mu \mathrm{M}$ quinine versus water ${ }^{\mathrm{b}}$ & 2 \\
\hline $80 \mu \mathrm{M}$ quinine versus water ${ }^{\mathrm{b}}$ & 2 \\
\hline
\end{tabular}

Notes: a Tap water was available in both drinking bottles. 'In all the two-bottle tests, the drinking bottles were rotated daily to prevent position preference.
Water and ethanol intakes were recorded every day to the nearest $0.1 \mathrm{~mL}$, and body weights were recorded every 4 days. To obtain an accurate measurement of ethanol and water consumption, the amount of daily alcohol and water intakes were determined (in $\mathrm{g}$ or $\mathrm{mL}$ per $\mathrm{kg}$ of body weight, respectively) for each animal and averaged over the 4-day period for each ethanol concentration. The ethanol preference, averaged over the 4-day period, was calculated as volume of ethanol consumed per total volume of water plus ethanol consumed. Total fluid intake, averaged over the 4-day period, was calculated and expressed as volume of water plus ethanol consumed per kilogram of body weight per day $\left(\mathrm{mL} / \mathrm{kg} /\right.$ day). ${ }^{30,31,35}$

For B428 dose response (second experiment), mice received saline and $\mathrm{B} 428(3,10$, or $30 \mathrm{mg} / \mathrm{kg}) \sim 30$ minutes prior to $10 \%$ ethanol and water access, at the beginning of the dark phase. Ethanol and water consumption were recorded over 24 hours, and results were expressed as described above. This pretreatment regimen created four test groups: $0 \mathrm{mg} / \mathrm{kg}(\mathrm{n}=7) ; 3 \mathrm{mg} / \mathrm{kg}(\mathrm{n}=7) ; 10 \mathrm{mg} / \mathrm{kg}(\mathrm{n}=9)$; and $30 \mathrm{mg} / \mathrm{kg}(\mathrm{n}=8)$.

\section{Two-bottle choice drinking procedure: 24-hour tastant access}

To assess whether the decreased ethanol consumption and preference may be due to the pharmacological effects of alcohol, the same mice were tested for increased consumption of nonalcohol tastants. Therefore, the same mice used in the first experiment were tested for saccharin (sweet) and quinine (bitter) intakes and preferences, using the same two-bottle choice paradigm as above. ${ }^{28,36,37}$ Specifically, 7 days after the ethanol consumption test, a 2-day saccharin drinking test was initiated, where the mice were given the choice between increasing concentrations of saccharin $(0.01 \%, 0.02 \%, 0.04 \%$, and $0.08 \% ; \mathrm{w} / \mathrm{v}$ ) and tap water. Therefore, mice were exposed to saccharin for a total 8 days (four concentrations of saccharin, each for 2 days). After completion of the saccharin drinking test and a respective 7-day washout period, mice were given access to increasing concentrations of quinine $(10,20,40$, and $80 \mu \mathrm{M} ; \mathrm{w} / \mathrm{v}$ ) and tap water. Therefore, mice were exposed to quinine for a total 8 days (four concentrations of quinine, each for 2 days). For both tastants, the drinking pipettes were randomly shifted every day to prevent position preference. Fluid intake (water, saccharin, or quinine) was measured daily, and body weights were recorded every 4 days throughout the whole study. Table 1 presents a general design of this experiment. For each fluid, an intake measure was obtained and averaged across a respective period of availability. 
Intake was then corrected for body weight of the subject. Preference for each substance was calculated according to the formula: (tastant intake/[tastant intake + water intake]) $\times 100 \%$. Total fluid intake was calculated and expressed as volume of water plus tastant consumed per kilogram of body weight per day (mL/kg/day). ${ }^{29,33,37}$

\section{Ethanol-induced CPP}

The ethanol-induced CPP was performed as described previously. ${ }^{27,29,31,34,37,38}$ Briefly, mice were trained in one of eight identical two-chamber place conditioning boxes. Two distinct environments $(30 \times 30 \times 30 \mathrm{~cm})$ that differed in color and floor texture were separated by a smaller central guillotine door. Each place conditioning experiment consisted of a 7-day schedule with three phases: preconditioning, conditioning, and postconditioning.

\section{Preconditioning}

During an initial baseline test, mice were placed in the center area and allowed to freely explore the apparatus for 15 minutes. Total time spent in each of the chambers was manually recorded to assess unconditioned preference. During this session, mice exhibiting unconditioned preference (more than 600 seconds) or aversion (less than 300 seconds) for any compartment were discarded from the conditioning session. In the particular experimental setup used in the current study, the mice did not show an unconditioned preference for either of the chambers $(440.2 \pm 11.01$ seconds [chamber A], 459.8 \pm 11.01 seconds [chamber B]), which supported our unbiased method. Thus, in one of the chambers A or B, randomly chosen, the mice received saline, and in the other, they were injected with ethanol.

\section{Conditioning}

This step was performed during 5 days and included two sessions each day. On the first day, the mice were conditioned for 30 minutes in one of the chambers, chosen as described above, immediately after IP injection of ethanol at 9:30-11:00 am (morning session). After 6 hours, the mice received a single IP injection of saline and were placed, for 30 minutes, in the opposing chambers chosen for the conditioning experiments (evening session). The animals were kept to one chamber by closing the guillotine door during these alternative sessions. On the second day of conditioning, the mice received the saline injections in the morning session and the ethanol injection in the evening session. The third and fifth day of conditioning had the same schedule as the first one. The fourth and sixth day of conditioning had the same schedule as the second one. This procedure had been chosen to control for circadian (morning/evening) variability. During each conditioning day, a mouse was conditioned with one vehicle-environment and one drug-environment pairing, separated by at least 6 hours. Groups were counterbalanced for drug order (morning or evening), drug side, and drug chamber association. In the CPP paradigm, B428 was given to the mice on all the 6 days, either in the morning or in the evening session. No significant differences were observed between groups for any of these variables.

This pretreatment-treatment combination created six test groups, consisting of three saline-saline conditioning groups (VEH [n=9], B428 $10 \mathrm{mg} / \mathrm{kg}$ [n=12], and B428 $30 \mathrm{mg} / \mathrm{kg}[\mathrm{n}=10])$ and three saline-ethanol conditioning groups (VEH [n=10], B428 $10 \mathrm{mg} / \mathrm{kg}[\mathrm{n}=11]$, and B428 $30 \mathrm{mg} / \mathrm{kg}[\mathrm{n}=10])$.

\section{Postconditioning}

On day 8, 24 hours after the final conditioning session, a 15-minute CPP test was carried out in the same manner as the initial baseline test. Therefore, the guillotine door was opened, and the mice were allowed free access to both chambers. No ethanol injection was given on the CPP test day. Then, the time spent in the ethanol paired chamber was monitored for each mouse, and the change of preference was calculated as the difference between the time spent in the ethanol-paired chamber on the postconditioning, and the time spent in this chamber on the preconditioning day.

\section{Blood ethanol concentration}

In a separate study, alcohol naïve male adult mice were used to test the effect of B428 on ethanol pharmacokinetics when given an equal amount of ethanol $(\mathrm{g})$ per $\mathrm{kg}$ of body weight, according to previously published methods. ${ }^{30,36,37}$ Mice were injected with B428 $(0,10$, or $30 \mathrm{mg} / \mathrm{kg})(\mathrm{n}=6$ each) and then returned to their home cages. After 30 minutes, mice were treated with a $3 \mathrm{~g} / \mathrm{kg}$ dose of ethanol (IP; $20 \% \mathrm{v} / \mathrm{v}$ in isotonic saline), and trunk blood samples were taken for blood ethanol concentration (BEC) analysis of ethanol metabolism kinetics at 1, 3, and 6 hours after injection. Blood samples were dispensed into a microcentrifuge tube containing $50 \mu \mathrm{L}$ ethylenediaminetetraacetic acids (EDTA) and centrifuged at 3,000 rpm for 10 minutes. The supernatant was removed and frozen until use. BECs (expressed in $\mathrm{g} / \mathrm{dL}$ ) were determined from serum, using an alcohol dehydrogenase assay from BioVision Research Products (CA, USA) and a standard ethanol concentration curve, according to the manufacturer instructions. 


\section{Statistical analysis}

For statistical comparisons, the software package IBM SPSS Statistics for Windows Version 21 was used. Data were expressed as means \pm standard error of the mean (SEM). The effects of B428 on ethanol (or tastant) consumption and preference were analyzed using a one-way, repeated measures analysis of variance (ANOVA), with drug (vehicle or B428) as the between-subjects factor and ethanol (or tastant) concentration as the within-subjects factor. The effects of B428 dose on ethanol consumption and preference was analyzed using a one-way ANOVA. The effect of B428 on the ethanol-induced CPP acquisition was analyzed using two-way ANOVA with repeated measures, with drug (vehicle or B428) and conditioning (ethanol or saline) as the between-subject factor and time (pre- and postconditioning) as the within-subject factor. The data representing the effect of B428 on BEC were analyzed using a two-way ANOVA, with drug and time as the between-subjects factors. Following a significant $F$-value, post hoc analyses (Bonferroni test) were performed for assessing specific group comparisons. The level of statistical significance was set at $P \leq 0.05$.

\section{Results}

\section{uPA inhibition decreased voluntary ethanol intake and preference}

In this experiment, we assessed oral ethanol consumption and preference, using a two-bottle preference paradigm, by giving mice continuous access to two drinking $10 \mathrm{~mL}$ pipettes: one containing tap water and the other containing an ascending range of ethanol concentrations. Average daily water intake $(\mathrm{mL} / \mathrm{kg})$ is shown in Figure 1A; the one-way ANOVA repeated measures revealed no significant effect of treatment $\left(F_{(1,30)}=1.407, P=0.245\right)$. However, there was a significant effect of ethanol concentration $\left(F_{(3,90)}=15.246, P<0.000\right)$. Most importantly, the interaction between treatment and ethanol concentration was found significant $\left(F_{(3,90)}=4.679, P=0.004\right)$. Follow-up paired-sample $t$-tests indicated that at the $10 \%$ ethanol concentration, B428 significantly increased water intake relative to vehicle $(P<0.001)$. No significant differences emerged in the analysis of the $2.5 \%, 5 \%$, and $20 \%$ concentrations ( $P=0.142, P=0.130$, and $P=0.214$, respectively). Analysis of the ethanol intake $(\mathrm{mL} / \mathrm{kg})$ indicated a significant effect of treatment $\left(F_{(1,30)}=6.480, P=0.016\right)$ and ethanol concentration $\left(F_{(3,90)}=27.235, P<0.0001\right)$, and most importantly, the treatment $\times$ ethanol concentration interaction $\left(F_{(3,90)}=27.235\right.$, $P<0.0001$ ) was found significant (Figure 1B). Follow-up post hoc tests indicated that at the $2.5 \%$ ethanol concentration,
B428 had no effect on ethanol drinking ( $P=0.649$ versus vehicle). However, significant differences emerged in the analysis of the $5 \%, 10 \%$, and $20 \%$ concentrations ( $P=0.009$, $P=0.004$, and $P<0.0001$, respectively) with B428-induced reduction of ethanol intake compared with vehicle. Average daily ethanol consumption, expressed as grams of ethanol per $\mathrm{kg}$ of body weight, is shown in Figure 1C, and the oneway ANOVA repeated measures revealed that there was a main effect of treatment $\left(F_{(1,30)}=18.516, P<0.000\right)$ and ethanol concentration $\left(F_{(3,90)}=160.251, P<0.000\right)$ on daily ethanol consumption. Interestingly, the interaction between treatment and concentration was significant $\left(F_{(3,90)}=6.398\right.$, $P=0.001$ ). Post hoc analysis indicated that B428-injected mice consumed less ethanol than vehicle, when given access to the $5 \%, 10 \%$, and $20 \%$ ethanol solution $(P<0.01)$. Ethanol preference was related to ethanol concentration in an inverted U-shaped manner, the maximal preference being obtained at $10 \%$ ethanol (approximately $80 \%$ preference). One-way ANOVA analysis indicated that ethanol preference was affected by treatment $\left(F_{(1,30)}=8.813, P=0.006\right)$ and by ethanol concentration $\left(F_{(3,90)}=35.748, P<0.000\right)$. Similarly, the treatment $\times$ concentration interaction was also significant $\left(F_{(3,90)}=4.787, P=0.004\right)$ (Figure 1D). Post hoc analysis indicated that B428-injected mice preferred less ethanol than vehicle when given access to the $5 \%, 10 \%$, and $20 \%$ ethanol solution $(P<0.05)$. Finally no treatment differences in total fluid intake were observed at any of the concentrations of alcohol tested in the two-bottle choice procedure $\left(F_{(1,30)}=1.172, P=0.288\right)$. In addition, the main effect of ethanol concentration $\left(F_{(3,9)}=0.389, P=0.761\right)$ and the interaction between treatment and concentration were not significant $\left(F_{(3,90)}=0.859, P=0.465\right)$ (data not shown).

\section{uPA inhibition did not affect tastants consumption and preference}

Ethanol and water likely have different tastes; thus, the lower drinking of ethanol by the B428-injected mice is not likely to be due to a difference in taste sensitivity between the two groups. However, to be more certain, we investigated this possibility with a sweet and a bitter tastant, using the same mice, and results are depicted in Figure 2. Daily water intake $(\mathrm{mL} / \mathrm{kg})$ is shown in Figure $2 \mathrm{~A}$; the one-way ANOVA repeated measures revealed no significant effect of treatment $\left(F_{(1,30)}=0.001, P=0.993\right)$, but there was a significant effect of saccharin concentration $\left(F_{(3,90)}=7.566, P<0.000\right)$. Interestingly, the treatment $\times$ saccharin concentration interaction was not significant $\left(F_{(3,90)}=0.212, P=0.888\right)$. Analysis of the saccharin intake $(\mathrm{mL} / \mathrm{kg})$ indicated no significant 
A

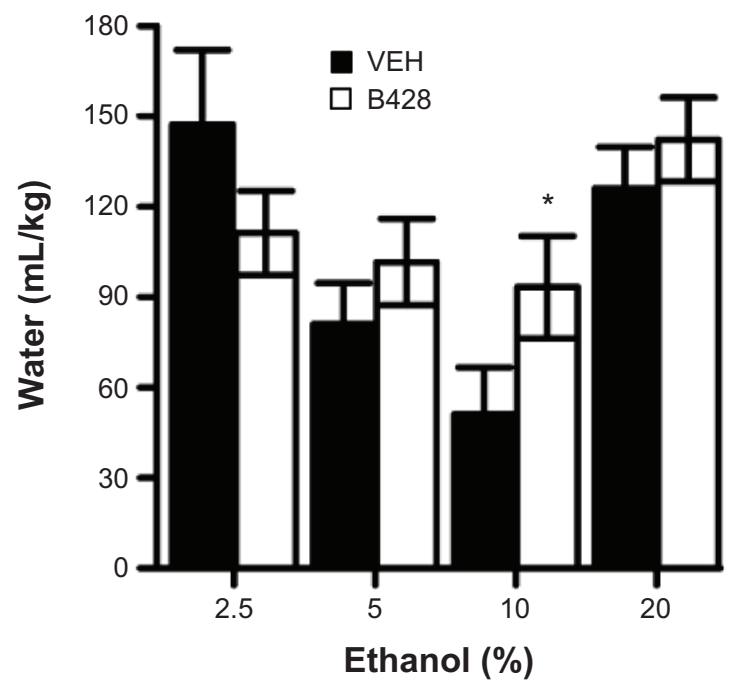

C

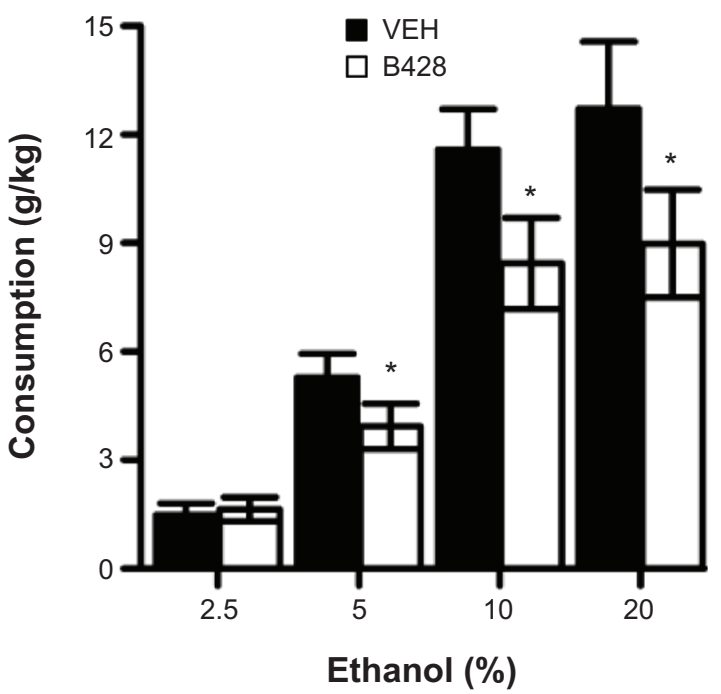

B

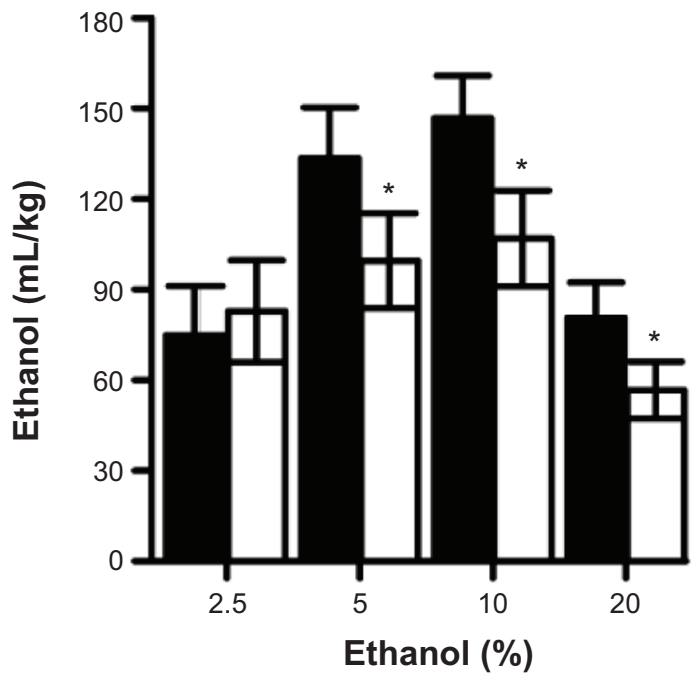

D

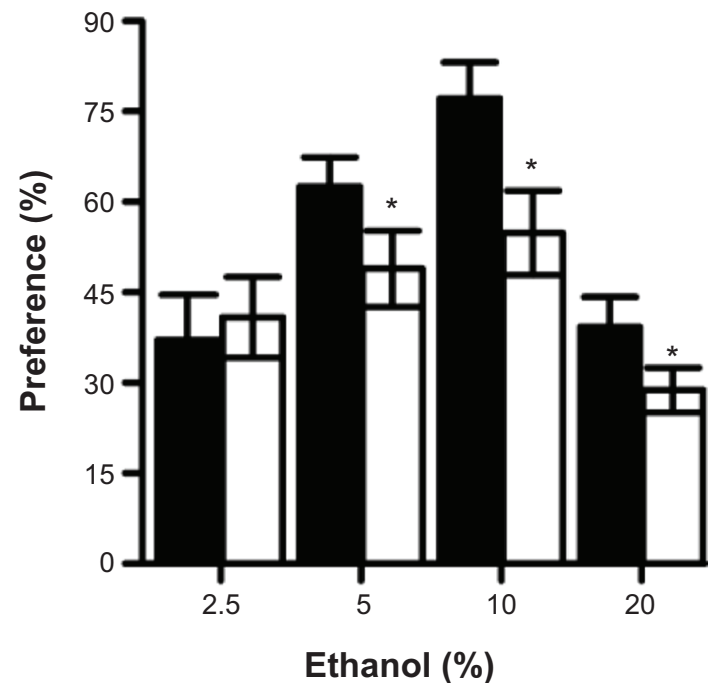

Figure I Effect of vehicle and B428 (10 mg/kg) on ethanol $(2.5 \%, 5 \%, 10 \%$, and $20 \%)$ consumption and preference.

Notes: (A) Water and (B) ethanol consumption, calculated as milliliters of water or ethanol consumed per kilogram of body weight, in male C57BL/6 mice. (C) Ethanol consumption, calculated as grams of alcohol consumed per kilogram of body weight, in male C57BL/6 mice. (D) Ethanol preference, expressed as ethanol consumed/total fluid consumed. Data are expressed as mean \pm SEM. $* P<0.05$ (versus vehicle). $n=16$ (vehicle), $n=16$ (B428). Closed bars: vehicle. Open bars: B428.

Abbreviations: SEM, standard error of the mean; VEH, vehicle.

effect of treatment $\left(F_{(1,30)}=0.011, P=0.918\right)$ or saccharin concentration $\left(F_{(3,90)}=0.997, P=0.398\right)$, and most importantly, the treatment $\times$ saccharin concentration interaction $\left(F_{(3,90)}=0.049, P=0.986\right)$ was not significant (Figure 2B). Although the mice consumed more saccharin when the higher concentrations were available than when the lower concentration was offered; main effect of concentration: $\left(F_{(3,90)}=102.040, P<0.000\right)$, the saccharin intake was similar for the two experimental groups; main effect of treatment: $\left(F_{(1,30)}=0.011, P=0.917\right)$. Also, the interaction between treatment and concentration $\left(F_{(3,90)}=0.042, P=0.989\right)$ was not significant (Figure 2C). Similarly, both vehicle- and B428-treated mice showed an increasing preference for saccharin with increasing concentrations $\left(F_{(3,90)}=4.406\right.$, $P=0.006$ ) (Figure 2D). However, no significant main effect of treatment $\left(F_{(1,30)}=0.014, P=0.905\right)$ or treatment $\times$ concentration $\left(F_{(3,90)}=0.186, P=0.96\right)$ were found on saccharin preference. Finally, the total amount of fluid consumed per day $(\mathrm{mL} / \mathrm{kg} /$ day) also did not change with increasing concentration $\left(F_{(3,90)}=0.736, P=0.533\right)$. No significant main 
A

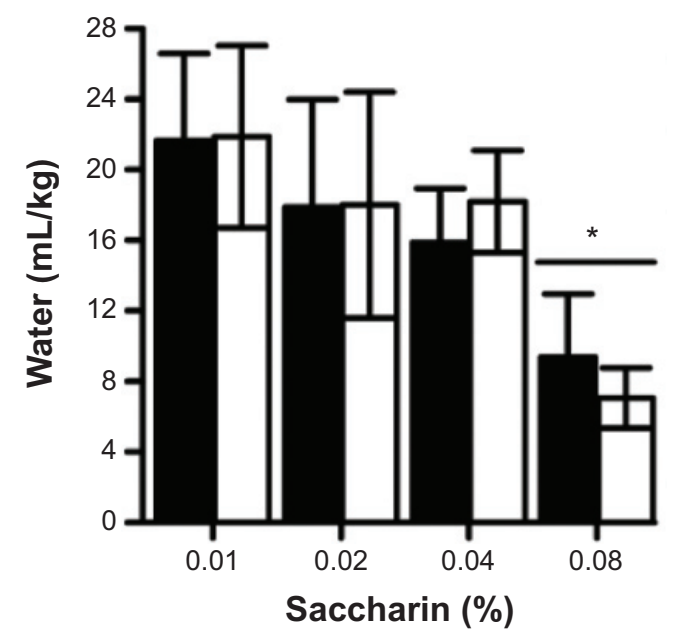

C

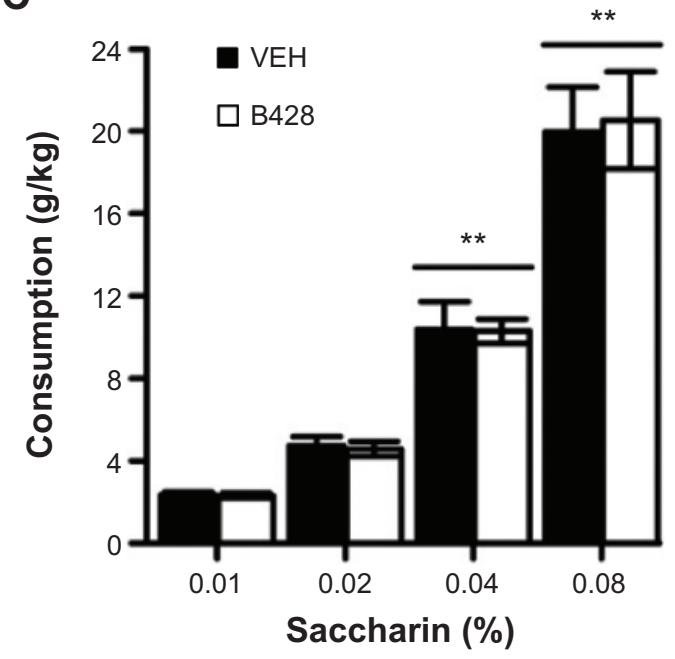

B

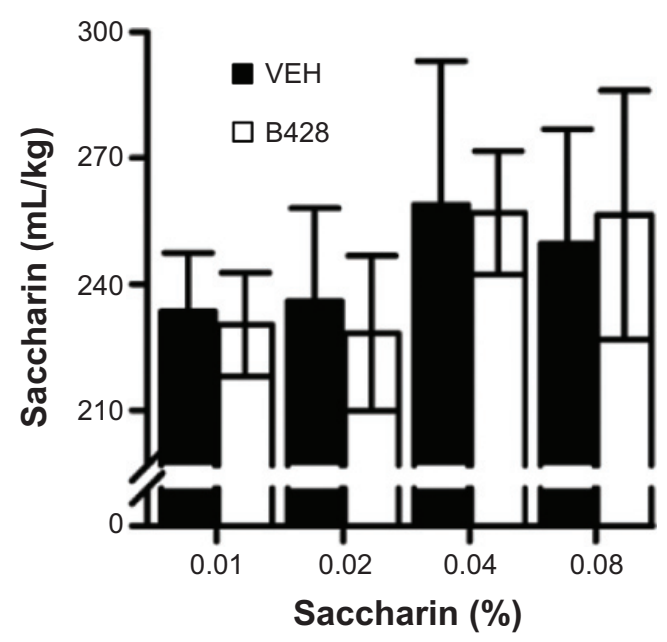

D

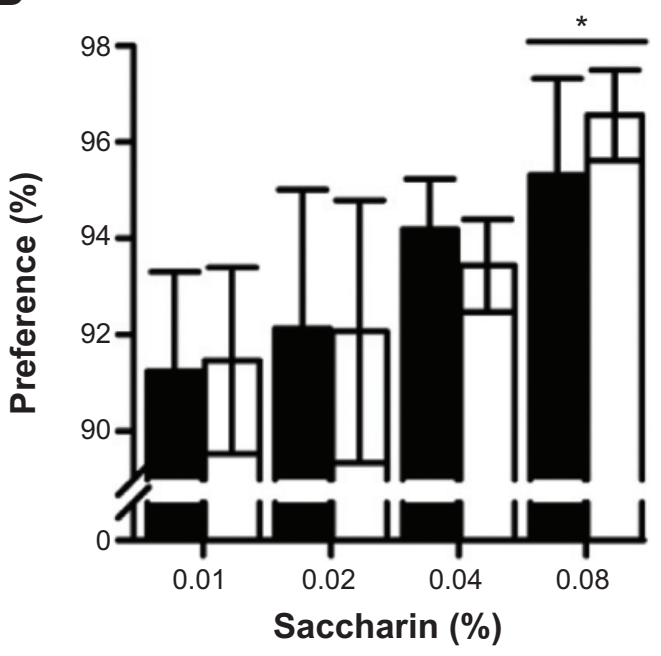

Figure 2 Effect of vehicle and B428 $(10 \mathrm{mg} / \mathrm{kg})$ on saccharin $(0.01 \%-0.08 \%)$ consumption and preference.

Notes: (A) Water and (B) saccharin consumption, calculated as milliliters of water or saccharin consumed per kilogram of body weight, in male C57BL/6 mice. (C) Saccharin consumption, calculated as grams of saccharin consumed per kilogram of body weight, in male C57BL/6 mice. (D) Saccharin preference, expressed as saccharin consumed/ total fluid consumed. Data are expressed as mean \pm SEM. $* P<0.05$ (versus $0.01 \%$ saccharin), $* * P<0.01$ (versus $0.01 \%$ saccharin). $n=16$ (vehicle), $n=16$ ( $B 428$ ). Closed bars: vehicle. Open bars: B428.

Abbreviations: SEM, standard error of the mean; VEH, vehicle.

effect of treatment was found $\left(F_{(1,30)}=0.008, P=0.930\right)$, with B428-injected mice showing similar total fluid intake at both concentrations tested compared with vehicle-treated mice. Overall, no interactions were found between treatment and concentration on the amount of fluid consumed $\left(F_{(3,90)}\right.$ $=0.039, P=0.990)$ (data not shown).

Daily water intake $(\mathrm{mL} / \mathrm{kg})$ is shown in Figure $3 \mathrm{~A}$; the one-way ANOVA repeated measures revealed no significant effect of treatment $\left(F_{(1,30)}=0.044, P=0.836\right)$ or quinine concentration $\left(F_{(3,90)}=0.529, P=0.664\right)$ on water consumption. Also, the interaction between the two variables was not significant $\left(F_{(3,90)}=0.446, P=0.721\right)$. In addition, there was no significant effect of treatment $\left(F_{(1,30)}=0.076, P=0.784\right)$ or saccharin concentration $\left(F_{(3,90)}=0.160, P=0.923\right)$ on quinine intake $(\mathrm{mL} / \mathrm{kg})$. In addition, the treatment $\times$ quinine concentration interaction $\left(F_{(3,90)}=0.187, P=0.905\right)$ was not significant (Figure 3B). Similar to ethanol and saccharin, the mice consumed increasing amounts of quinine per day (mg/kg/day) with increasing quinine concentrations (main effect of concentration: $F_{(3,90)}=65.802, P<0.000$ ). However, no significant effect was found either for treatment $\left(F_{(1,30)}=0.000, P=0.998\right)$ or for concentration $\times$ treatment interaction $\left(F_{(3,90)}=0.024, P=0.995\right)$ (Figure $\left.3 \mathrm{C}\right)$. For quinine preference, there was a tendency to prefer less quinine when the higher concentrations were offered, but statistical analysis did not reveal a significant effect of concentration $\left(F_{(3,90)}=0.752, P=0.524\right)$. In addition, there was no difference between the two groups in quinine preference (main 
A

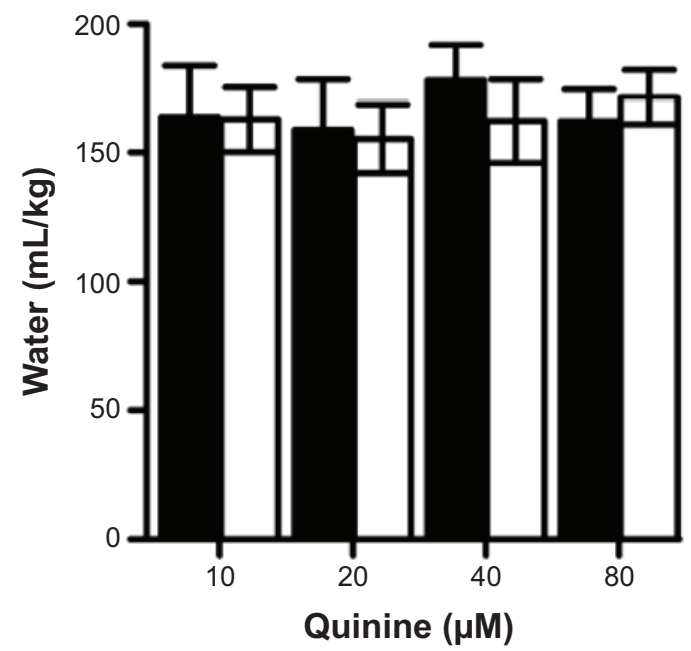

C

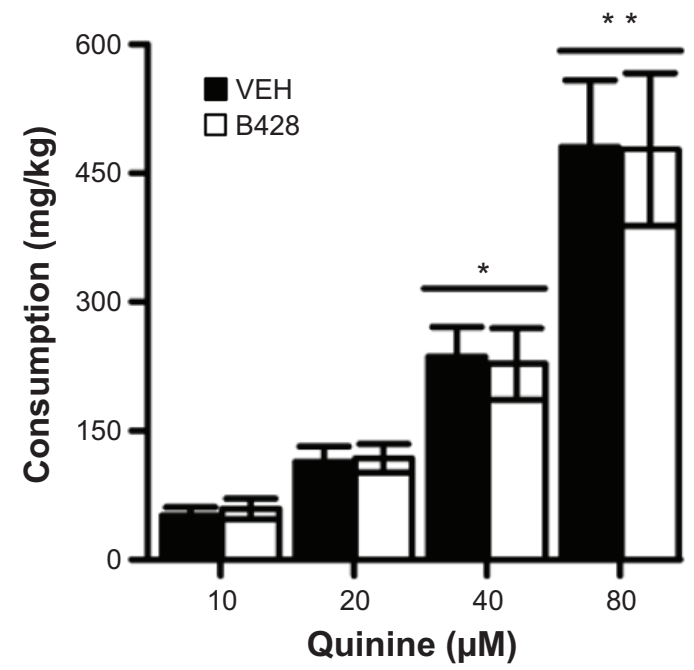

B

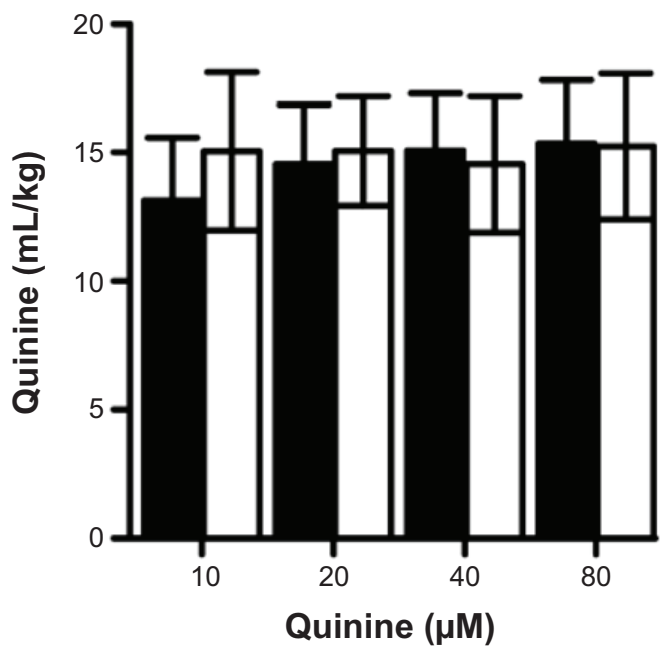

D

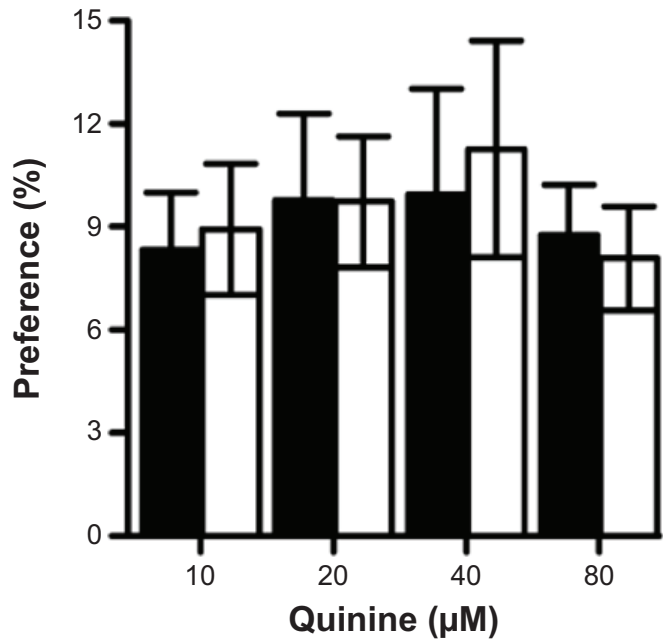

Figure 3 Effect of vehicle and B428 $(10 \mathrm{mg} / \mathrm{kg})$ on quinine $(10-80 \mu \mathrm{M})$ consumption and preference.

Notes: (A) Water and (B) quinine consumption, calculated as milliliters of water or quinine consumed per kilogram of body weight, in male C57BL/6 mice. (C) Quinine consumption, calculated as milligrams of quinine consumed per kilogram of body weight, in male C57BL/6 mice. (D) Quinine preference, expressed as quinine consumed/ total fluid consumed. Data are expressed as mean \pm SEM. $* P<0.05$ (versus $10 \mu M$ quinine), $* * P<0.01$ (versus I0 $\mu M$ quinine). $n=16$ (vehicle), $n=16$ (B428). Closed bars: vehicle. Open bars: B428.

Abbreviations: SEM, standard error of the mean; VEH, vehicle.

effect of treatment: $\left.F_{(1,30)}=0.080, P=0.780\right)$. Also, the interaction between treatment and concentration was not significant $\left(F_{(3,90)}=0.132, P=0.941\right)$ (Figure 3D). Finally, the total fluid intake consumed per day $(\mathrm{mL} / \mathrm{kg} /$ day $)$ did not depend on the quinine concentration $\left(F_{(3,90)}=0.543\right.$, $P=0.654)$ and did not differ between vehicle and $\mathrm{B} 428$ groups (main effect of treatment: $F_{(1,30)}=0.027, P=0.870$ ) (data not shown).

These data suggest that differences in taste sensitivity are unlikely to have played a significant role in the treatment difference (vehicle versus B428) in ethanol consumption and preference. Overall, these results suggest that uPA activity is an important contributor to mechanisms that underlie the motivation to consume alcohol.

\section{B428 dose-dependently decreased ethanol consumption and preference}

Next, different groups of mice $(n=7-9)$ were exposed to a two-bottle free-choice paradigm with ethanol (10\%) and tap water, and we tested the effects of a range of B428 doses $(0,3,10$, and $30 \mathrm{mg} / \mathrm{kg})$ on ethanol and water intake, and preference. Therefore, C57BL/6 mice were trained to drink $10 \%$ alcohol versus water under a two-bottle choice, homecage, continuous access to alcohol paradigm, and the results 
A

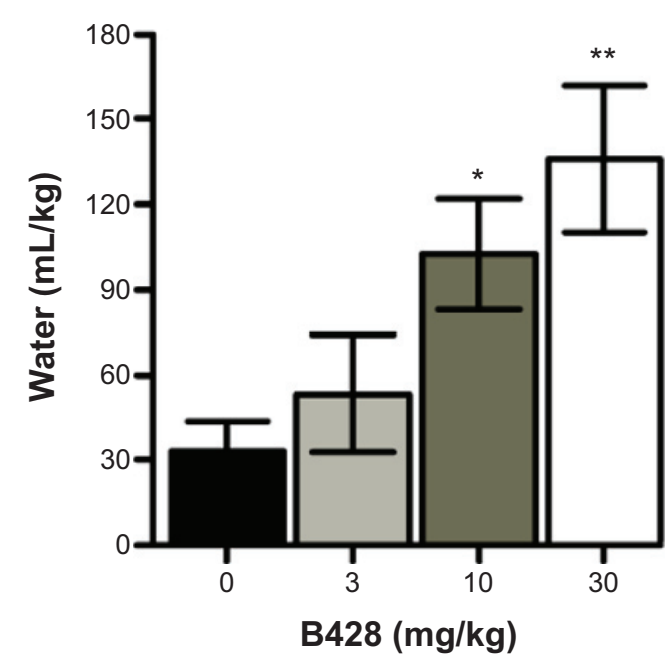

C

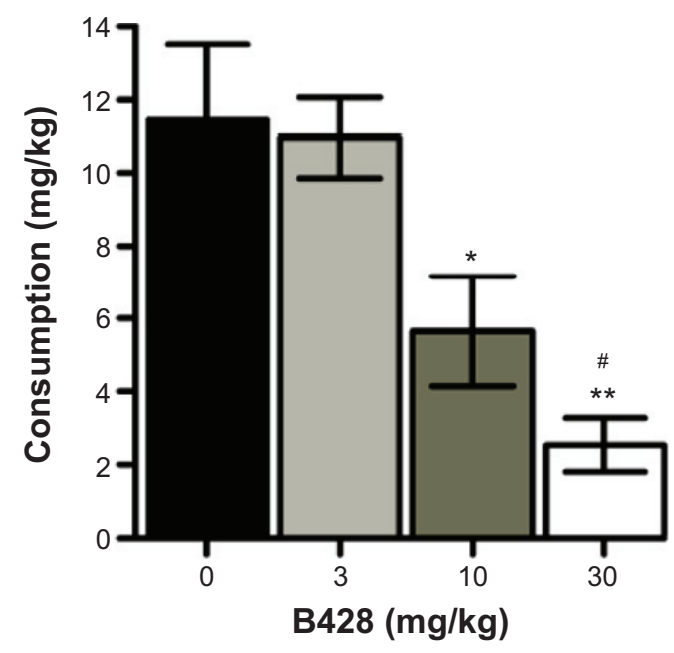

B

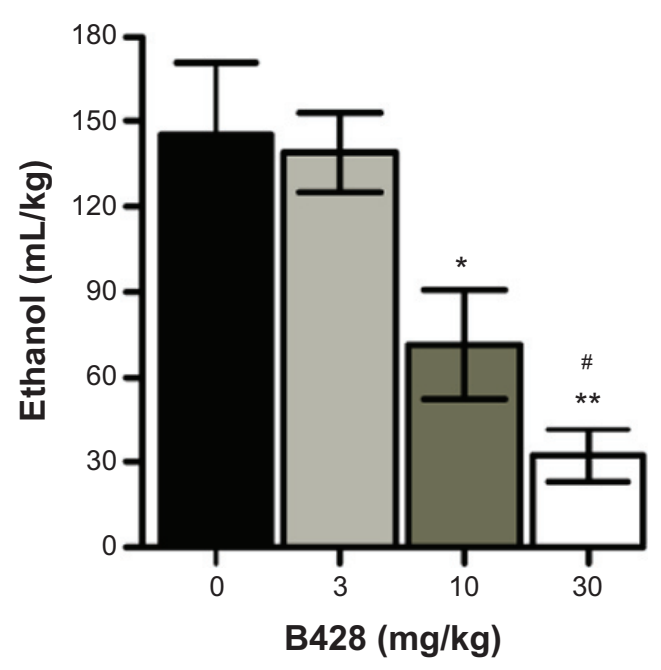

D

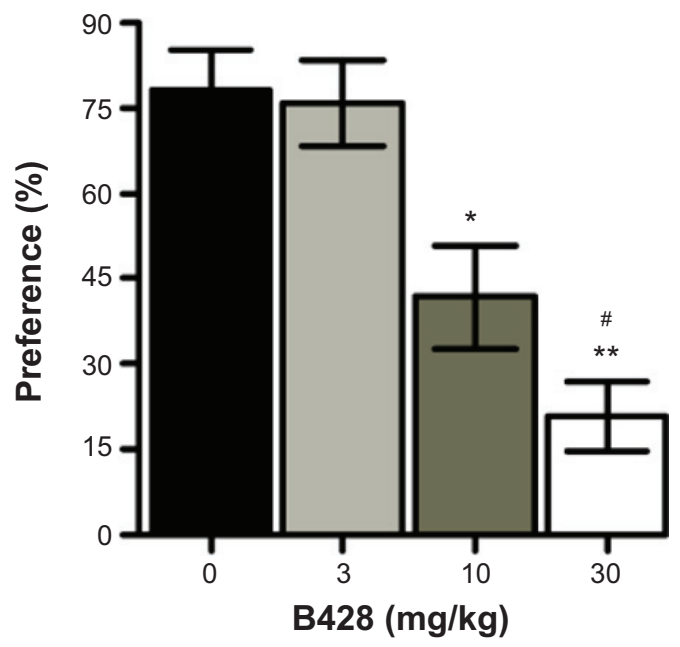

Figure 4 Effect of B428 $(0,3,10$, and $30 \mathrm{mg} / \mathrm{kg})$ on ethanol (10\%) consumption and preference.

Notes: (A) Water and (B) ethanol consumption, calculated as milliliters of water or ethanol consumed per kilogram of body weight, in male C57BL/6 mice. (C) Ethanol consumption, calculated as grams of alcohol consumed per kilogram of body weight, in male C57BL/6 mice. (D) Ethanol preference, expressed as ethanol consumed/total fluid consumed. Data are expressed as mean \pm SEM. ${ }^{*} P<0.01$ (versus $0 \mathrm{mg} / \mathrm{kg}$ ), ${ }^{* *} P<0.00 \mathrm{I}$ (versus $\left.0 \mathrm{mg} / \mathrm{kg}\right),{ }^{\#} P<0.05$ (versus $\left.10 \mathrm{mg} / \mathrm{kg}\right) . \mathrm{n}=7$ (0 mg/kg), $\mathrm{n}=7$ ( $\left.3 \mathrm{mg} / \mathrm{kg}\right), \mathrm{n}=9$ $(10 \mathrm{mg} / \mathrm{kg})$, and $\mathrm{n}=8(30 \mathrm{mg} / \mathrm{kg})$.

Abbreviation: SEM, standard error of the mean.

are presented in Figure 4. Average daily water intake $(\mathrm{mL} / \mathrm{kg})$ is shown in Figure 4A; the one-way ANOVA indicated a main effect of B428 dose $\left(F_{(3,27)}=21.910, P<0.000\right)$. Follow-up paired-sample $t$-tests revealed a dose-dependent increase in water intake $(P<0.001)$ with 10 and $30 \mathrm{mg} / \mathrm{kg}$ compared with $0 \mathrm{mg} / \mathrm{kg}$. In contrast, no significant effect on water intake was observed with low dose of B428 (3 mg/kg) $(P=1.000)$ compared with control. The effect of B428 dose on ethanol intake $(\mathrm{mL} / \mathrm{kg})$ is depicted in Figure 4B. As expected, data analysis revealed a significant effect of B428 $\left(F_{(3,27)}=30.764\right.$, $P<0.000)$. Post hoc analysis showed that compared with control, mice consumed less alcohol when injected with 10 and $30 \mathrm{mg} / \mathrm{kg} \mathrm{B} 428(P<0.001$ and $P<0.000$, respectively).
In addition, there was a significant difference between 10 and $30 \mathrm{mg} / \mathrm{kg}(P=0.035)$. As for ethanol consumption, calculated as grams per kilogram of body weight, the oneway ANOVA revealed that B428 significantly and dosedependently reduced alcohol consumption determined after 24 hours access to alcohol $\left(F_{(3,27)}=30.781, P<0.000\right)$. Post hoc evaluation indicated that as expected, B428 $(10 \mathrm{mg} / \mathrm{kg})$ significantly reduced ethanol intake, by approximately $50 \%$ compared with control $(P<0.000)$. Also, the $30 \mathrm{mg} / \mathrm{kg}$ dose significantly reduced ethanol intake post-24-hour treatment, by $80 \%$ and $50 \%$ compared with control and $10 \mathrm{mg} / \mathrm{kg}$, respectively $(P<0.000$ and $P=0.035)$. However, no significant effect on ethanol intake was observed with low dose of B428 
(3 mg/kg) ( $P=1.000)$ (Figure 4C). Similarly and as depicted in Figure 4D, pretreatment with B428 resulted in a dosedependent reduction in the ethanol preference $\left(F_{(3,27)}=37.537\right.$, $P<0.000$ ). Specifically, alcohol preference in 10 and $30 \mathrm{mg} / \mathrm{kg}$ B428-treated mice was approximately $50 \%$ and $75 \%$ lower, respectively, than that recorded in saline-dosed mice $(P<0.001)$. In contrast, in the $3 \mathrm{mg} / \mathrm{kg}$ B 428 -treated mouse group, mice were completely devoid of any response to the ethanol exposure as their ethanol preference was approximately $97 \%$ similar to the control group $(P=1.000)$. In addition, there was a significant difference between the 10 and $30 \mathrm{mg} / \mathrm{kg}$ B428 doses $(P=0.011)$ with respect to ethanol preference. Finally, no differences between any of the groups of mice were observed in total fluid consumption, whatever the B428 dose concentration used. In fact, the one-way ANOVA test revealed no significant effect of treatment on total fluid intake $\left(F_{(3,27)}=0.831, P=0.488\right)$ (data not shown).

Thus, B428 potently reduced alcohol intake in C57BL/6 mice, with no effect on total fluid intake, suggesting that B428 effects on mice alcohol intake occurred through a specific reduction of alcohol consumption rather than nonspecific motor effects. Taken together, the B428-induced anti-alcohol effects are considered to have certain selectivity and specificity as the reduction of voluntary ethanol intake coincided with a reduction of ethanol preference.

\section{B428-inhibited uPA activity impaired ethanol-induced CPP}

The CPP procedure was used to investigate whether B428 affected the rewarding properties of ethanol and whether B428 by itself induced rewarding or aversive effects. The timeline of the experiments is depicted in Figure 5A and B. As can be seen in Figure $5 \mathrm{C}$, ethanol $(1.5 \mathrm{~g} / \mathrm{kg})$ produced an increase of time spent in the drug-paired chamber in mice (main effect of ethanol conditioning: $\left.F_{(1,56)}=37.621, P<0.000\right)$. Interestingly, administration of B428 (10 or $30 \mathrm{mg} / \mathrm{kg}$ ) 30 minutes before saline or ethanol injection reduced the preference time induced by ethanol (main effect of treatment: $F_{(2,56)}=10.062$, $P=0.043$ ). Most importantly, a two-way ANOVA of treatment and conditioning (saline versus ethanol) revealed an interaction between these two factors $\left(F_{(2,56)}=9.812, P<0.000\right)$. Tests of the within-subject factors indicated that there was a significant effect of time $\left(F_{(1,56)}=33.205, P<0.000\right)$, a significant time $\times$ treatment interaction $\left(F_{(2,56)}=10.062, P<0.000\right)$, a significant time $\times$ conditioning interaction $\left(F_{(1,56)}=37.621\right.$, $P<0.000)$, and a significant time $\times$ conditioning $\times$ treatment interaction $\left(F_{(2,45)}=9.812, P<0.000\right)$ detected. Post hoc analysis showed that when conditioned with ethanol

\section{A}

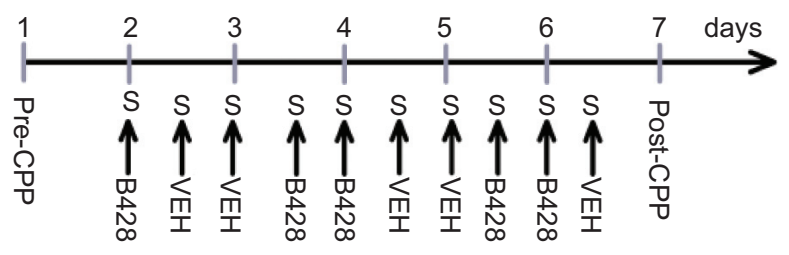

\section{B}
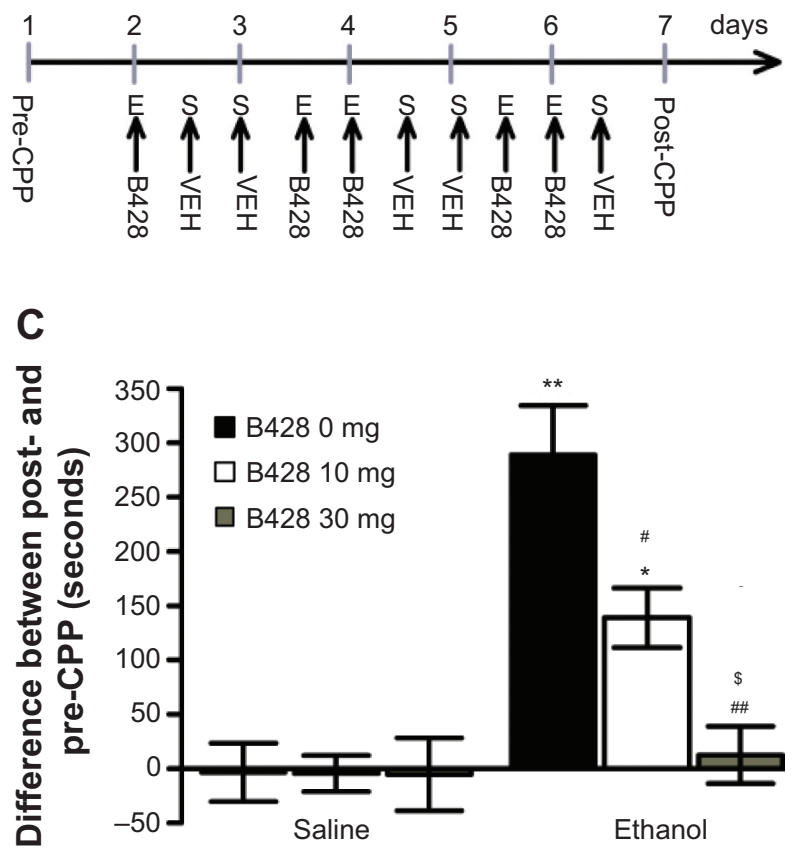

Figure 5 Effect of B428 $(0,10$, and $30 \mathrm{mg} / \mathrm{kg})$ on ethanol-elicited conditioned place preference.

Notes: Experimental procedures for (A) saline-saline and (B) saline-ethanol conditioning. (C) Ethanol-elicited place preference test, expressed as mean time \pm SEM (seconds) spent on the ethanol paired box (test minus habituation). Male C57BL/6 mice in the conditioning subgroups had previously received pairings of B428 $(0,10$, or $30 \mathrm{mg} / \mathrm{kg}$ ) before saline or ethanol $(1.5 \mathrm{~g} / \mathrm{kg}$; IP). $* P<0.05$ (versus saline conditioning), $* * P<0.01$ (versus saline conditioning), ${ }^{\#} P<0.05$ (versus $B 4280 \mathrm{mg} / \mathrm{kg}$ ), ${ }^{\#} P<0.01$ (versus B428 $0 \mathrm{mg} / \mathrm{kg}$ ), ${ }^{\$} P<0.05$ (versus B428 $10 \mathrm{mg} / \mathrm{kg}$ ). Saline-saline conditioning: $\mathrm{n}=9(\mathrm{~B} 4280 \mathrm{mg} / \mathrm{kg}), \mathrm{n}=12(\mathrm{~B} 42810 \mathrm{mg} / \mathrm{kg})$, and $\mathrm{n}=10(B 42830 \mathrm{mg} / \mathrm{kg})$. Saline-ethanol conditioning: $n=10$ (B428 0 mg/kg), $n=1$ I (B428 $10 \mathrm{mg} / \mathrm{kg})$, and $\mathrm{n}=10$ (B428 $30 \mathrm{mg} / \mathrm{kg})$. Abbreviations: CPP, conditioned place preference; E, ethanol; IP, intraperitoneal; $\mathrm{S}$, saline; SEM, standard error of the mean; VEH, vehicle.

and compared with vehicle (Figure 5), 10 and $30 \mathrm{mg} / \mathrm{kg}$ B428 significantly inhibited CPP expression $(P=0.012$ and $P<0.001$, respectively). Interestingly, there was a significant difference between 10 and $30 \mathrm{mg} / \mathrm{kg}(P=0.039)$.

\section{B428 had no effect on blood ethanol concentration}

Finally, the BEC in vehicle- and B428-injected mice was assessed in order to test whether the B428 utilized in this study was eliciting its effect by altering alcohol absorption and metabolism. Animals were injected with B428 
$(0,10$, or $30 \mathrm{mg} / \mathrm{kg}$; $\mathrm{n}=6$ each) 30 minutes before alcohol administration $(3 \mathrm{~g} / \mathrm{kg}$ ). BEC (in $\mathrm{g} / \mathrm{dL}$ ) were determined by collecting blood 1,3 , and 6 hours after alcohol administration, and the results are depicted in Table 2. The twoway ANOVA with drug and time as the between-subject factors revealed a main effect of time $\left(F_{(2,45)}=25.613\right.$, $P<0.000)$, with BECs significantly greater at 1 hour than at $3(P=0.023)$ and 6 hours $(P<0.000)$ postethanol. However, the rate of alcohol metabolism, as measured by the slope of the line, was not significantly different between the three groups $\left(F_{(2,45)}=0.182, P=0.834\right)$. Interestingly, the interaction between treatment and time was not significant $\left(F_{(2,45)}=0.258, P=0.903\right)$. Thus, there was no evidence that ethanol pharmacokinetics was affected by preexposure to 10 or $30 \mathrm{mg} / \mathrm{kg} \mathrm{B} 428$.

\section{Discussion}

In the present study, we have demonstrated that, using the two-bottle choice drinking paradigm under unlimited access conditions, the specific brain penetrant uPA inhibitor, B428, dose-dependently reduced ethanol consumption and preference, whereas intake of the nonalcohol tastants saccharin and quinine, were not affected. More importantly, systemic injection of B428 prior to each ethanol conditioning impaired ethanol-induced CPP expression.

The continuous unlimited drinking paradigm used in the current study was chosen for multiple reasons. First, when rodents have continuous access to ethanol in the home cage $24 \mathrm{~h} /$ day, ethanol consumption is necessarily related to the pharmacological effects of alcohol. In addition, continuous unlimited access procedures are also more appropriate to study the pharmacological effects of compounds with long elimination half-lives, such as B428, in rodents and other small animals. ${ }^{25,39}$ Along these lines, a previous study from our laboratory has shown that in Wistar rats, B428 blocked cocaine-induced psychomotor stimulation. ${ }^{21}$ In agreement with the current findings, we have also shown in a previous study that ethanol treatment dose-dependently

Table 2 Blood ethanol concentration

\begin{tabular}{llll}
\hline & I hour & 3 hours & 6 hours \\
\hline B428 $0 \mathrm{mg} / \mathrm{kg}$ & $328.4 \pm 43.6$ & $222.4 \pm 56.8^{*}$ & $52.3 \pm 14$. I** $^{*}$ \\
$\mathrm{~B} 42810 \mathrm{mg} / \mathrm{kg}$ & $352.0 \pm 68.5$ & $218.3 \pm 51.8^{*}$ & $96.5 \pm 26.7^{* *}$ \\
$\mathrm{~B} 42830 \mathrm{mg} / \mathrm{kg}$ & $307.4 \pm 45.2$ & $250.5 \pm 30.3^{*}$ & $83.0 \pm 24.9^{* *}$ \\
\hline
\end{tabular}

Notes: Mice were injected with B428 $(0,10$, or $30 \mathrm{mg} / \mathrm{kg})$, and 30 minutes later, they received an acute injection of ethanol $(3 \mathrm{~g} / \mathrm{kg})$. Blood ethanol concentrations, expressed in $\mathrm{g} / \mathrm{dL}$, were measured I, 3 , and 6 hours later. Data are expressed as mean \pm SEM. $N=6$ in each group. ${ }^{*} P<0.05$ (versus I hour), ${ }^{* * P}<0.0$ I (versus I hour). Abbreviation: SEM, standard error of the mean. induced the expression and the enzymatic activity of another serine protease, namely, tissue plasminogen activator (tPA), in the NAc. ${ }^{32}$ More importantly, ethanol-induced locomotor stimulation, behavioral sensitization and CPP were enhanced following tPA overexpression in the NAc, when examined using a lentiviral vector. However, knockdown of tPA expression with specific siRNA-expressing lentiviral vectors blocked the rewarding properties of ethanol. ${ }^{32}$

The CPP paradigm is assumed to reflect the secondary motivational properties of drugs and their potential for abuse. ${ }^{40}$ The CPP procedure is very useful for distinguishing between the effects of drugs on acquisition versus expression of learning. ${ }^{41,42}$ In the present study, systemic administration of $1.5 \mathrm{~g} / \mathrm{kg}$ of ethanol during five conditioning sessions, using an unbiased paradigm, induced robust CPP. Our result is similar to previously reported studies that indicated that a moderate dose of ethanol $(1.5-2 \mathrm{~g} / \mathrm{kg})$ produced a significant CPP in C57BL/6 mice. ${ }^{43-46}$ Our previous research revealed that the systemic administration of B428 impaired cocaine-induced CPP, ${ }^{21}$ suggesting that uPA inhibition can impair the capacity of environmental cues that are associated with psychostimulation to elicit approach behavior. In this study, the same dose of B428 did influence the acquisition of the CPP response to ethanol, which is consistent with our previous finding on tPA. ${ }^{32}$ For CPP acquisition/learning, the stimulus must be rewarding and the animals must associate the rewarding effects with environmental cues (associative learning). Disruption of one of these processes is manifested as a reduced preference for the drug-paired compartment. ${ }^{47,48}$ The fact that B428 blocked the acquisition of ethanol-induced CPP indicates that uPA activity is critical for one or both of the aforementioned processes.

Most studies examining the behavioral, neuroanatomical, and neurochemical mechanisms underlying ethanol consumption and preference have implicated glutamate, dopamine, serotonin, gamma-aminobutyric acid (GABA), and several other neuropeptides in very specific circuitries of the brain, such as the mesocorticolimbic reward system, the amygdala, and other limbic brain regions. ${ }^{49-53}$ These regions contain considerable amounts of uPA expression. ${ }^{3,13,19,20}$ Therefore, future studies examining the contribution of uPA in localized specific brain regions are needed, to determine the neurobiological mechanism(s) by which uPA inhibition using B428 reduces ethanol consumption and preference. In addition, more studies are needed to determine whether uPA mediates ethanol consumption and preference via genomic or nongenomic mechanisms. The fact that effects were observed, in the present study, within 24 hours of 
B428 administration suggests possible dual actions of uPA in mediating these phenomena.

In conclusion, the present study demonstrates, for the first time, the involvement of uPA in voluntary ethanol consumption and preference as well as in the conditioned rewarding effects of ethanol in adult mice. In particular, this serine protease was shown to be involved in the acquisition of ethanol-induced CPP. Such new knowledge concerning the neurobiological basis of the rewarding effects of ethanol may be of help in designing adequate therapies for users who become dependent or are concerned about their use of alcohol. In addition, future studies examining the ability of selective B428-like uPA inhibitors to reduce ethanol consumption and preference using other rodent models of alcoholism (ie, operant self-administration, relapse) may uncover novel therapeutic approaches for the treatment of alcoholism and excessive ethanol intake in humans.

\section{Acknowledgments}

This work was supported by grants from the United Arab Emirates University and the National Research foundation.

The authors are grateful to Dr Bruce A Littlefield of Eisai, Inc., Andover, MA, USA, for providing B428. The authors would like to acknowledge Mr Mohamed Elwasila and Mr Mohamed Shafiullah for their technical assistance, and Dr Mahmoud Hag Ali, of the Central Animal Facility, for his advice on veterinary care.

\section{Author contributions}

$\mathrm{AB}$ was responsible for the study concept and design. EA, $\mathrm{SA}, \mathrm{MA}$, and $\mathrm{AB}$ contributed to the acquisition of animal data. AB performed the data analysis, and EA, SA, and MA helped in the interpretation of findings. EA and AB drafted the manuscript. All the authors provided critical revision of the manuscript for important intellectual content, reviewed content, and approved the final version for publication.

\section{Disclosure}

The authors report no conflicts of interest in this work.

\section{References}

1. Rehm J, Taylor B, Room R. Global burden of disease from alcohol, illicit drugs and tobacco. Drug Alcohol Rev. 2006;25(6):503-513.

2. Blackwell DL, Lucas JW, Clarke TC. Summary health statistics for US adults: National Health Interview Survey, 2012. National Center for Health Statistics. Vital Health Stat. 2014;10(260):1-171. Available from: http://www.cdc.gov/nchs/data/series/sr_10/sr10_260.pdf. Accessed August 25, 2014.

3. Galliciotti G, Sonderegger P. Neuroserpin. Front Biosci. 2006;11:33-45.
4. Yoshida S, Shiosaka S. Plasticity-related serine proteases in the brain (review). Int J Mol Med. 1999;3(4):405-409.

5. Yamada K, Nagai T, Nabeshima T. Drug dependence, synaptic plasticity, and tissue plasminogen activator. J Pharmacol Sci. 2005;97(2):157-161.

6. Yamada K. Endogenous modulators for drug dependence. Biol Pharm Bull. 2008;31(9):1635-1638.

7. Li D, Liu S, Shan H, Conti P, Li Z. Urokinase plasminogen activator receptor (uPAR) targeted nuclear imaging and radionuclide therapy. Theranostics. 2013;3(7):507-515.

8. O'Halloran TV, Ahn R, Hankins P, Swindell E, Mazar AP. The many spaces of UPAR: delivery of theranostic agents and nanobins to multiple tumor compartments through a single target. Theranostics. 2013; 3(7):496-506

9. Persson M, Kjaer A. Urokinase-type plasminogen activator receptor (UPAR) as a promising new imaging target: potential clinical applications. Clin Physiol Funct Imaging. 2013;33(5):329-337.

10. Małgorzewicz S, Skrzypczak-Jankun E, Jankun J. Plasminogen activator inhibitor-1 in kidney pathology (Review). Int J Mol Med. 2013; 31(3):503-510.

11. Mekkawy AH, Pourgholami MH, Morris DL. Involvement of urokinasetype plasminogen activator system in cancer: an overview. Med Res Rev. Epub 2014 Feb 18

12. Taubert H, Magdolen V, Kotzsch M. Impact of expression of the uPA system in sarcomas. Biomark Med. 2013;7(3):473-480.

13. Masos T, Miskin R. Localization of urokinase-type plasminogen activator mRNA in the adult mouse brain. Brain Res Mol Brain Res. 1996; 35(1-2):139-148.

14. Meiri N, Masos T, Rosenblum K, Miskin R, Dudai Y. Overexpression of urokinase-type plasminogen activator in transgenic mice is correlated with impaired learning. Proc Natl Acad Sci U S A. 1994;91(8): 3196-3200.

15. Froy O, Chapnik N, Miskin R. Long-lived alphaMUPA transgenic mice exhibit pronounced circadian rhythms. Am J Physiol Endocrinol Metab. 2006;291(5):E1017-E1024.

16. Miskin R, Masos T. Transgenic mice overexpressing urokinase-type plasminogen activator in the brain exhibit reduced food consumption, body weight and size, and increased longevity. J Gerontol A Biol Sci Med Sci. 1997;52(2):B118-B124.

17. Bahi A, Boyer F, Gumy C, Kafri T, Dreyer JL. In vivo gene delivery of urokinase-type plasminogen activator with regulatable lentivirus induces behavioural changes in chronic cocaine administration. Eur J Neurosci. 2004;20(12):3473-3488.

18. Bahi A, Boyer F, Kafri T, Dreyer JL. Silencing urokinase in the ventral tegmental area in vivo induces changes in cocaine-induced hyperlocomotion. J Neurochem. 2006;98(5):1619-1631.

19. Bahi A, Dreyer JL. Overexpression of plasminogen activators in the nucleus accumbens enhances cocaine-, amphetamine- and morphineinduced reward and behavioral sensitization. Genes Brain Behav. 2008; 7(2):244-256.

20. Bahi A, Kusnecov A, Dreyer JL. The role of tissue-type plasminogen activator system in amphetamine-induced conditional place preference extinction and reinstatement. Neuropsychopharmacology. 2008; 33(11):2726-2734.

21. Bahi A, Kusnecov AW, Dreyer JL. Effects of urokinase-type plasminogen activator in the acquisition, expression and reinstatement of cocaine-induced conditioned-place preference. Behav Brain Res. 2008; 191(1):17-25.

22. Evans DM, Sloan-Stakleff KD. Maximum effect of urokinase plasminogen activator inhibitors in the control of invasion and metastasis of rat mammary cancer. Invasion Metastasis. 1998;18(5-6):252-260.

23. Xing RH, Mazar A, Henkin J, Rabbani SA. Prevention of breast cancer growth, invasion, and metastasis by antiestrogen tamoxifen alone or in combination with urokinase inhibitor B428. Cancer Res. 1997;57(16): 3585-3593. 
24. Rabbani SA, Harakidas P, Davidson DJ, Henkin J, Mazar AP. Prevention of prostate-cancer metastasis in vivo by a novel synthetic inhibitor of urokinase-type plasminogen activator (uPA). Int J Cancer. 1995; 63(6):840-845.

25. Alonso DF, Farías EF, Ladeda V, Davel L, Puricelli L, Bal de Kier Joffé E. Effects of synthetic urokinase inhibitors on local invasion and metastasis in a murine mammary tumor model. Breast Cancer Res Treat. 1996;40(3):209-223.

26. Ridker PM, Vaughan DE, Stampfer MJ, Glynn RJ, Hennekens CH. Association of moderate alcohol consumption and plasma concentration of endogenous tissue-type plasminogen activator. JAMA. 1994; 272(12):929-933.

27. Bahi A. The selective metabotropic glutamate receptor 7 allosteric agonist AMN082 prevents reinstatement of extinguished ethanol-induced conditioned place preference in mice. Pharmacol Biochem Behav. 2012; 101(2):193-200.

28. Bahi A. Individual differences in elevated plus-maze exploration predicted higher ethanol consumption and preference in outbred mice. Pharmacol Biochem Behav. 2013;105:83-88.

29. Bahi A. Increased anxiety, voluntary alcohol consumption and ethanolinduced place preference in mice following chronic psychosocial stress. Stress. 2013;16(4):441-451.

30. Bahi A. Viral-mediated knockdown of mGluR7 in the nucleus accumbens mediates excessive alcohol drinking and increased ethanol-elicited conditioned place preference in rats. Neuropsychopharmacology. 2013; 38(11):2109-2119.

31. Bahi A, Dreyer JL. Involvement of nucleus accumbens dopamine D1 receptors in ethanol drinking, ethanol-induced conditioned place preference, and ethanol-induced psychomotor sensitization in mice. Psychopharmacology (Berl). 2012;222(1):141-153.

32. Bahi A, Dreyer JL. Involvement of tissue plasminogen activator "tPA" in ethanol-induced locomotor sensitization and conditioned-place preference. Behav Brain Res. 2012;226(1):250-258.

33. Bahi A, Dreyer JL. Striatal modulation of BDNF expression using microRNA124a-expressing lentiviral vectors impairs ethanol-induced conditioned-place preference and voluntary alcohol consumption. Eur J Neurosci. 2013;38(2):2328-2337.

34. Bahi A, Dreyer JL. Chronic psychosocial stress causes delayed extinction and exacerbates reinstatement of ethanol-induced conditioned place preference in mice. Psychopharmacology (Berl). 2014;231(2): 367-377.

35. Bahi A, Fizia K, Dietz M, Gasparini F, Flor PJ. Pharmacological modulation of mGluR7 with AMN082 and MMPIP exerts specific influences on alcohol consumption and preference in rats. Addict Biol. 2012;17(2):235-247.

36. Bahi A, Sadek B, Schwed SJ, Walter M, Stark H. Influence of the novel histamine $\mathrm{H}_{3}$ receptor antagonist ST1283 on voluntary alcohol consumption and ethanol-induced place preference in mice. Psychopharmacology (Berl). 2013;228(1):85-95.

37. Bahi A, Tolle V, Fehrentz JA, et al. Ghrelin knockout mice show decreased voluntary alcohol consumption and reduced ethanol-induced conditioned place preference. Peptides. 2013;43:48-55.
38. Crabbe JC, Phillips TJ, Feller DJ, et al. Elevated alcohol consumption in null mutant mice lacking 5-HT1B serotonin receptors. Nat Genet. 1996;14(1):98-101.

39. Alonso DF, Tejera AM, Farias EF, Bal de Kier Joffe E, Gomez DE. Inhibition of mammary tumor cell adhesion, migration, and invasion by the selective synthetic urokinase inhibitor B428. Anticancer Res. 1998;18(6A):4499-4504.

40. Witt ED. Mechanisms of alcohol abuse and alcoholism in adolescents: a case for developing animal models. Behav Neural Biol. 1994; 62(3):168-177.

41. Napier TC, Herrold AA, de Wit H. Using conditioned place preference to identify relapse prevention medications. Neurosci Biobehav Rev. 2013;37(9 Pt A):2081-2086.

42. Schechter MD, Calcagnetti DJ. Trends in place preference conditioning with a cross-indexed bibliography; 1957-1991. Neurosci Biobehav Rev. 1993;17(1):21-41.

43. Hilbert ML, May CE, Griffin WC. Conditioned reinforcement and locomotor activating effects of caffeine and ethanol combinations in mice. Pharmacol Biochem Behav. 2013;110:168-173.

44. Gamsby JJ, Templeton EL, Bonvini LA, et al. The circadian Per1 and Per2 genes influence alcohol intake, reinforcement, and blood alcohol levels. Behav Brain Res. 2013;249:15-21.

45. Griffin WC, McGovern RW, Bell GH, Randall PK, Middaugh LD, Patrick KS. Interactive effects of methylphenidate and alcohol on discrimination, conditioned place preference and motor coordination in C57BL/6J mice. Psychopharmacology (Berl). 2013;225(3):613-625.

46. Koenig HN, Olive MF. Ethanol consumption patterns and conditioned place preference in mice lacking preproenkephalin. Neurosci Lett. 2002; 325(2):75-78.

47. Sanchis-Segura C, Spanagel R. Behavioural assessment of drug reinforcement and addictive features in rodents: an overview. Addict Biol. 2006;11(1):2-38.

48. Le Foll B, Goldberg SR. Control of the reinforcing effects of nicotine by associated environmental stimuli in animals and humans. Trends Pharmacol Sci. 2005;26(6):287-293.

49. Tabakoff B, Hoffman PL. The neurobiology of alcohol consumption and alcoholism: an integrative history. Pharmacol Biochem Behav. 2013;113:20-37.

50. Williams RW, Lu L. Integrative genetic analysis of alcohol dependence using the GeneNetwork web resources. Alcohol Res Health. 2008; 31(3):275-277.

51. Nam HW, McIver SR, Hinton DJ, et al. Adenosine and glutamate signaling in neuron-glial interactions: implications in alcoholism and sleep disorders. Alcohol Clin Exp Res. 2012;36(7):1117-1125.

52. McGregor IS, Bowen MT. Breaking the loop: oxytocin as a potential treatment for drug addiction. Horm Behav. 2012;61(3):331-339.

53. Ross S, Peselow E. The neurobiology of addictive disorders. Clin Neuropharmacol. 2009;32(5):269-276.

54. Petrakis IL. A rational approach to the pharmacotherapy of alcohol dependence. J Clin Psychopharmacol. 2006;26(Suppl 1):S3-S12.

\section{Publish your work in this journal}

Drug Design, Development and Therapy is an international, peerreviewed open-access journal that spans the spectrum of drug design and development through to clinical applications. Clinical outcomes, patient safety, and programs for the development and effective, safe, and sustained use of medicines are a feature of the journal, which

\section{Dovepress}

has also been accepted for indexing on PubMed Central. The manuscript management system is completely online and includes a very quick and fair peer-review system, which is all easy to use. Visit http://www.dovepress.com/testimonials.php to read real quotes from published authors. 